taining table grape postharvest quality for long distance markets. Proc. Int. Symp. Table Grape Production. 28-29 June, Anaheim, Calif. p. 195-199.

Harvey, J.M., C.M. Harris, T.A. Hanke, and P.L Hartsell. 1988. Sulfur dioxide fumigation of table grapes: relative sorption of $\mathrm{SO}_{2}$ by fruit and packages, $\mathrm{SO}_{2}$ residues, decay, and bleaching. Amer. J. Enol. Viticult. 39:132-136.

Jacob, H.E. 1924. The use of sulfur dioxide in shipping grapes. Univ. Calif., Berkeley, Bul. 471 .

Luvisi, D.A., H.H. Shorey, J.L. Smilanick, J.F. Thompson, B.H. Gump, and J. Knutson. 1992. Sulfur dioxide fumigation of table grapes. Bulletin 1932. Univ. Calif. Div. Agr. Natural Resources, Oakland.

Luvisi, D.A., H.H. Shorey, J.F. Thompson, T. Hinsch, and D. Slaughter. 1995. Packaging California table grapes. Univ. Calif. Div. Agr. Natural Resources, Oakland, Bul. 1934.

Marois, J.J., A.M. Bledsoe, W.D. Gubler, and D.A. Luvisi. 1986. Control of Botrytis cinerea on grape berries during postharvest storage with reduced levels of sulfur dioxide. Plant Dis. 70:1050-1052.

Nelson, K.E. 1985. Harvesting and handling California table grapes for market. Univ. Calif. Div. Agr. Natural Resources, Oakland, Bul. 1913.

Nelson, K.E. 1991. The grape, p. 125167. In: N.A.M. Eskin (ed.). Quality and preservation of fruit. CRC Press, Boca Raton, Fla.

Palou, L., C.H. Crisosto, J.L. Smilanick, J.E. Adaskaveg, and J.P. Zoffoli. 2001.
Effects of continuous 0.3 ppm ozone exposure on decay development and physiological responses of peaches and table grapes in cold storage. Postharvest Biol. Technol. (in press).

Ryall, A.L. and J.M. Harvey. 1959. The cold storage of vinifera table grapes. USDA Agr. Hdbk. 159.

Santiago, M.S. and T.A. Hanke. 2000. Comparison between two different types of $\mathrm{SO}_{2}$ pads on 'hairline' split level of table grapes cv. Thompson Seedless. Proc. 4th Int. Symp. Table Grape. 28 Nov.-1 Dec., La Serena, Chile. p. 97.

Smilanick, J.L. and D.J. Henson. 1992. Minimum gaseous sulphur dioxide concentration and exposure periods to control Botrytis cinerea. Crop Protection 11:535540 .

United States Environmental Protection Agency. 1986. Interim policy for sulfiting agents on grapes. Fed. Reg. 51:4724047241 .

Uota, M. and J.M. Harvey. 1964. Improved sulfur dioxide fumigation of grapes loaded in railway refrigerator cars. USDA Mkt. Res. Rpt. 642.

Zoffoli, J.P., J. Rodríguez, and E. Koehler. 2000. Puntos críticos en el manejo de postcosecha de uva de mesa-Efecto en la condición del racimo, p. 135-150. In: J. Pérez, S. Barros, M.C. Peppi, A. Pérez, and A. Vargas (eds.). Calidad y Condición de Llegada a los Mercados Extranjeros de la Uva de Mesa de Exportación Chilena. Colección de Extensión. Pontificia Universidad Católica de Chile, Facultad de Agronomía e Ingeniería Forestal (in Spanish).

\section{Legume and Grass Cover Crops for Seedless Watermelon Production}

\author{
M. Rangappa, ${ }^{1}$ A.A. Hamama, \\ and H.L. Bhardwaj
}

Additional indeX words. crimson clover, hairy vetch, rye, Secale cereale, Trifolium incarnatum, Vicia villosa, nitrogen fertilizer

Summary. Although there is increasing interest in reducing the use of nitrogen $(\mathrm{N})$ fertilizers due to the potential of unused $\mathrm{N}$ causing pollution of surface and groundwater, $\mathrm{N}$ is a major nutrient for plant growth. Our objective was to determine the potential of using winter legume cover crops to meet the $\mathbf{N}$ needs of seedless watermelon (Citrullus lanatus), a potential cash crop for farmers in Virginia. Fruit number, fruit weight, fruit yield, and fruit quality traits (flesh to rind ratio, water content, total soluble solids, sugar content, and $\mathrm{pH}$ ) of seedless watermelons were evaluated in replicated experiments in Virginia at three locations during 1997-98 and two locations during 1998-99 following cover crop treatments consisting of crimson clover (Trifolium incarnatum), hairy vetch (Vicia villosa), crimson clover + rye (Secale cereale), hairy vetch + rye, and a bareground control treatment that received $100 \mathrm{lb} /$ acre $\left(112 \mathrm{~kg} \cdot \mathrm{ha}^{-1}\right)$ of $\mathrm{N}$. At all five locations, the bareground control treatment resulted in fewer fruit [ 1803 fruit/acre $(4454$ fruit/ha)], lower fruit weight $[9.8 \mathrm{lb}$ $(4.5 \mathrm{~kg})]$, and lower fruit yield [8.9 tons/acre $\left.\left(20.0 \mathrm{t} \cdot \mathrm{ha}^{-1}\right)\right]$ compared to the four cover crop treatments. The crimson clover + rye and hairy vetch treatments resulted in highest number

Agricultural Research Station, Virginia State Univer sity, Petersburg, VA 23806.

Contribution of Virginia State University, Agricultural Research Station, journal article series 221. The use of trade names or vendors does not imply approval to the exclusion of other products or vendors that may also be suitable.

*Corresponding author: e-mail mrangapp@vsu.edu. 
of fruit [ 2866 and 2657 fruit/acre (7079 and 6563 fruit/ha), respectively], whereas the highest fruit yield was obtained following hairy vetch [21.2 tons/acre $\left(49.8 \mathrm{t} \cdot \mathrm{ha}^{-1}\right)$ ], hairy vetch + rye $[20.3$ tons/acre $(45.5$ $\left.\left.\mathrm{t} \cdot \mathrm{ha}^{-1}\right)\right]$, and crimson clover + rye [19.6 tons/acre $\left.\left(43.9 \mathrm{t} \cdot \mathrm{ha}^{-1}\right)\right]$. Cover crop treatments did not affect the quality of watermelon flesh. The seedless watermelon fruit averaged 1.4 flesh : 1 rind ratio, $90 \%$ water content, $9.5 \%$ total soluble solids, $8.0 \%$ sugar, and a $\mathrm{pH}$ value of 5.9 . These results indicated that legume cover crops, such as crimson clover and hairy vetch, can be successfully used to produce seedless watermelons, in a no-till system, without any use of $\mathrm{N}$ fertilizers with dryland conditions.

$1 \begin{aligned} & \text { gricultural practices are } \\ & \text { considered an important } \\ & \text { source of N pollution of water }\end{aligned}$ supplies (U.S. Environmental Protection Agency, 1992). Estimates of crop absorption of applied $\mathrm{N}$ range from $25 \%$ to $70 \%$ and efficiency decreases with increased fertilizer application (Hills et al., 1983). The unused $\mathrm{N}$ can increase soil salt content and crop production costs (Csizinsky and Schuster, 1982) and can lead to runoff and leaching (Doss et al., 1975), that contaminates surface and groundwater (Hallberg, 1987; Meisinger et al., 1991; National Research Council, 1989). Research studies (Abdul-Baki and Teasdale, 1993; Abdul-Baki et al., 1996 and 1997; Stivers and Shennan, 1991) have demonstrated that legume cover crops can reduce the need for commercial $\mathrm{N}$ fertilizer for tomato (Lycopersicon esculentum) production. There are few scientific reports of use of legume cover crops for production of seedless and seeded watermelons.

Seedless watermelon is generally considered a novelty crop that attracts consumers and usually sells for a premium as compared to the seeded watermelon. It has been observed commonly in local stores that the price of a comparable-sized seedless watermelon was almost double the price of a seeded watermelon. Therefore, it is probable that production of seedless watermelons as a specialty cash crop, with sustainable production technology, could increase farm income, and help in diversification of cropping system.

Aneed for development and adoption of crop production systems to conserve soil, maintain fertility, and reduce contamination of the environment coupled with a need for high value cash crops as alternatives for tobacco (Nicotiana tabacum) farmers and small farmers provided the impetus for this study. The objectives were to develop a seedless watermelon production system that relies on winter legume cover crops, thus, reducing use of supplemental inorganic $\mathrm{N}$ fertilizer and to evaluate the potential of producing seedless watermelons in this system.

\section{Materials and methods}

Field experiments were conducted at three locations (Petersburg, James City County, and King William County) during 1997-98 and two locations (Petersburg and Prince George County) during 1998-99 in Virginia on sandy loam soils (Table 1 ). In the case of the similar location, the experiments were conducted at different sites. At each location, five cover crop treatments (hairy vetch, crimson clover, hairy vetch + rye, crimson clover + rye, and a bare ground control receiving $100 \mathrm{lb} /$ acre of $\mathrm{N}$ ) were evaluated for their potential in supporting production of seedless watermelons.

The size of cover crop plots was $55 \times 25 \mathrm{ft}(16.5 \times 7.5 \mathrm{~m})$. All cover crop seed were planted broadcast and incorporated into the soil with a drag harrow during the fall season of 1997 and 1998. The plant material in all plots was killed using a treatment of glyphosate and paraquat herbicides at flower initiation of any cover crop. About 2 weeks after the burndown treatment, watermelon transplants were set by hand into mulch in each plot using a randomized complete block design with four replications. Each plot had four rows of a female (triploid) cultivar 'Summer Sweet 5544' (Abbott and Cobb, Feasterville, $\mathrm{Pa}$.) and two rows of a male pollinator cultivar 'Summer Flavor 500' (Abbott and Cobb) with rows $5 \mathrm{ft}$ apart and 3 $\mathrm{ft}$ space between plants $(1.5 \times 0.9 \mathrm{~m})$. Four-week-old watermelon transplants were set in the field on 18-19, 22-23, and 24 May 1998 at Petersburg, James City County, and King William County, respectively; and on 11-12 and 18-19 May 1999 at Petersburg and Prince George County, respectively. The cover crop plots did not receive any fertilizer while control plots received $100 \mathrm{lb} /$ acre of $\mathrm{N}$ as ammo- nium nitrate $(34 \mathrm{~N}-0 \mathrm{P}-0 \mathrm{~K})$. All plots received recommended herbicide treatments for weed control in watermelon (Virginia Cooperative Extension, 1997). Standard insect and disease control measures were used to prevent development of problems related to insect pests and diseases (Virginia Cooperative Extension, 1997). We did not place bee hives in these fields to facilitate cross pollination.

The watermelons were harvested once, at maturity (late August during both years), from all rows of each plot and data on number of fruit (fruit/ acre), fruit yield (tons/acre), and fruit weight (lb/fruit) were recorded. All data are based on four, $55 \mathrm{ft}(16.5 \mathrm{~m})$ long rows of female watermelon plants. In 1998 only, watermelon flesh from two representative fruit from each plot were evaluated to determine flesh:rind ratio, moisture content, total soluble solids (TSS), sugar content, and pH. A slice of tissue, approximately 4 inches $(10.2 \mathrm{~cm})$ wide was taken from the middle of each fruit, perpendicular to the blossom to stem-end plane, similar to the method of Chisholm and Picha (1986). The rind from these slices was separated from flesh and the fresh weights of rind and flesh (including occasional seeds) were recorded to calculate flesh:rind ratios. The flesh samples were dried for $24 \mathrm{~h}$ at $162^{\circ} \mathrm{F}$ $\left(72^{\circ} \mathrm{C}\right)$ to record the dry weight and for calculating moisture content in flesh. For determining $\mathrm{pH}$, TSS, and sugar content in the flesh, a sample was thoroughly homogenized in a high speed blender. A portion of the resultant slurry was centrifuged at $15,777 \mathscr{g}_{n}$ for $10 \mathrm{~min}$. TSS and $\mathrm{pH}$ were measured in an aliquot of the supernatant using the Fisher brand Abbe bench top refractometer and Accumet $\mathrm{PH}$ meter (Fisher Scientific Company, Suwanee, Ga.), respectively (Risse, et al., 1990). Total soluble sugars were colorimetrically determined as glucose in an aliquot of the supernatant using phenol-sulfuric acid method (Dubois et al., 1956).

All data, combined over five locations, were statistically analyzed using General Linear Models procedure in SAS (1996). The four cover crop treatments (crimson clover, hairy vetch, crimson clover + rye, and hairy vetch + rye) were compared to the bare-ground treatment (control) using Dunnett's test $(P=0.05)$. The four cover crop treatments were compared with each 
Table 1. Soil properties of five locations in Virginia for seedless watermelon experiments.

\begin{tabular}{|c|c|c|c|c|c|c|c|}
\hline \multirow[b]{2}{*}{ Location, year } & \multirow{2}{*}{$\begin{array}{c}\text { Rec-N }{ }^{z} \\
\text { (lb/acre) }\end{array}$} & \multirow{2}{*}{$\begin{array}{l}\mathbf{O M}^{\mathrm{y}} \\
(\%)\end{array}$} & $\mathbf{P}^{\mathbf{x}}$ & $\mathbf{K}$ & $\mathrm{mMg}$ & $\mathbf{C a}$ & \multirow[b]{2}{*}{ pH } \\
\hline & & & \multicolumn{4}{|c|}{$\left[p p m\left(m g \cdot k^{-1}\right)\right]$} & \\
\hline James City County, 1998 & $90-115^{\mathrm{w}}$ & 1.6 & 32 & 87 & 75 & 264 & 5.8 \\
\hline King William County, 1998 & $90-115$ & 1.7 & 22 & 75 & 93 & 447 & 6.2 \\
\hline Petersburg, 1998 & $90-115$ & 1.5 & 54 & 52 & 54 & 383 & 6.1 \\
\hline Petersburg, 1999 & $90-115$ & 1.5 & 77 & 54 & 68 & 395 & 6.4 \\
\hline Prince George County, 1999 & $15-40$ & 1.7 & 43 & 83 & 59 & 352 & 5.8 \\
\hline
\end{tabular}

${ }^{\mathrm{z}} \mathrm{Rec}-\mathrm{N}=$ nitrogen recommended by soil test for watermelon; $\mathrm{l} \mathrm{lb} / \mathrm{acre}=1.12 \mathrm{~kg} \cdot \mathrm{ha}^{-1}$.

y $\mathrm{OM}=$ organic matter.

${ }^{\mathrm{P}} \mathrm{P}=$ phosphorus, $\mathrm{K}=$ potassium, $\mathrm{Mg}=$ magnesium, $\mathrm{Ca}=$ calcium.

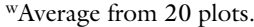

other using Duncan's new multiple range test $(P=0.05)$.

\section{Results and discussion}

Differences existed among five locations and five cover crop treatments in fruit number, fruit weight, and fruit yield (Table 2). The differences among cover crop treatments were significant for all locations except for the King William County location for fruit/acre and fruit yield. Location effects were significant only for flesh:rind ratio and TSS (Table 3 ). The effects of cover crop treatments on chemical composition of seedless watermelons were not significant.

At all five locations, the bareground plots had the lowest fruit number, fruit weight, and fruit yield as compared to the four cover crop treat- ments (Table 2). The crimson clover + rye and hairy vetch treatments resulted in the highest number of fruit/acre. The greatest fruit weight was observed in the hairy vetch and hairy vetch + rye treatments. The cover crop treatments consisting of hairy vetch, hairy vetch + rye, and crimson clover + rye resulted in the highest fruit yields which were significantly superior to those following crimson clover alone (Table 2).

The five locations differed for fruit number/acre, fruit weight, and fruit yield (Table 2). The Petersburg location, during both 1998 and 1999, had highest fruit/acre and fruit yield while the King William County location had the lowest fruit/acre, fruit weight, and fruit yield. It was not possible to attribute the differences among locations to the variation in soil properties
(Table 1). Within the five locations (Table 3 ), the four cover-crop treatments resulted in superior yield of seedless watermelons over bare-ground treatment except for the King William County location in 1998.

Cover crops did not affect the chemical composition of seedless watermelons. The seedless watermelon fruit averaged 1.4 flesh : 1 rind ratio, $90 \%$ water content, $9.5 \%$ TSS, $8.0 \%$ sugar, and a $\mathrm{pH}$ value of 5.9. Locations differed in flesh:rind ratio and TSS. The flesh:rind ratio from King William County (1.6:1) was superior to that from the James City County and Petersburg locations (both 1.3:1). The percent TSS from the Petersburg location $(10.1 \%)$ was superior to that from King William County $(9.0 \%)$ and not different from James City County (9.5\%).

Table 2. Performance of seedless watermelon following five cover crop treatments at five locations in Virginia.

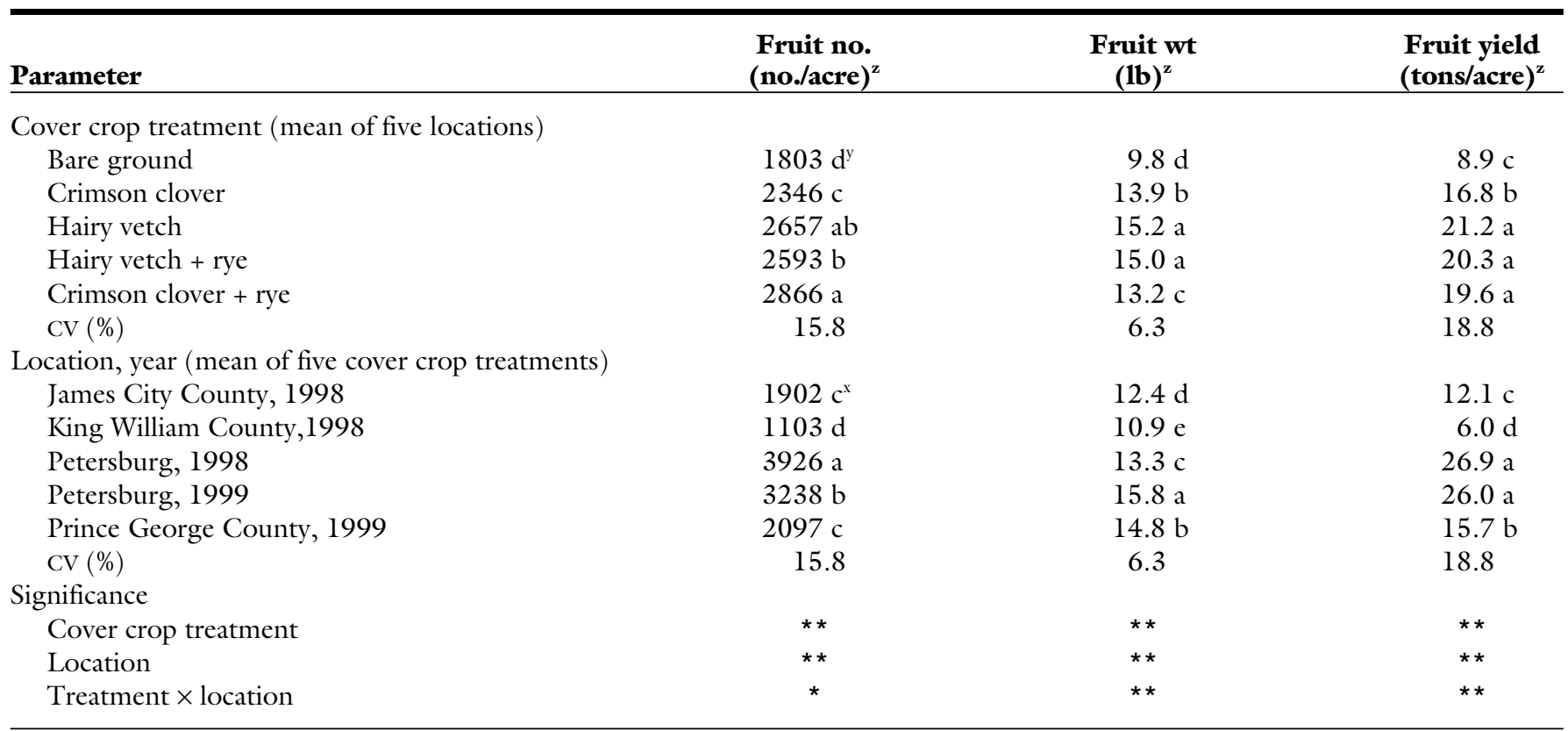

${ }^{\mathrm{z}} \mathrm{l}$ fruit $/$ acre $=2.5$ fruit $/ \mathrm{ha} ; 1.0 \mathrm{lb}=0.45 \mathrm{~kg} ; 1.0 \mathrm{ton} / \mathrm{acre}=2.24 \mathrm{t} \cdot \mathrm{ha}^{-1}$.

yThe cover crop treatments were compared with the bare-ground treatment (control) using Dunnett's procedure whereas the four cover crop treatments were compared to each other using Duncan's new multiple range test $(P=0.05)$. Means followed by similar letters are not different at $P=0.05$.

${ }^{x}$ Means followed by similar letters are not different according to Duncan's new multiple range test $(P=0.05)$.

, ,* Significant at $P=0.5$ and 0.01 . respectively. 
Table 3. Cover crop treatments and location effects on performance of seedless watermelon in Virginia.

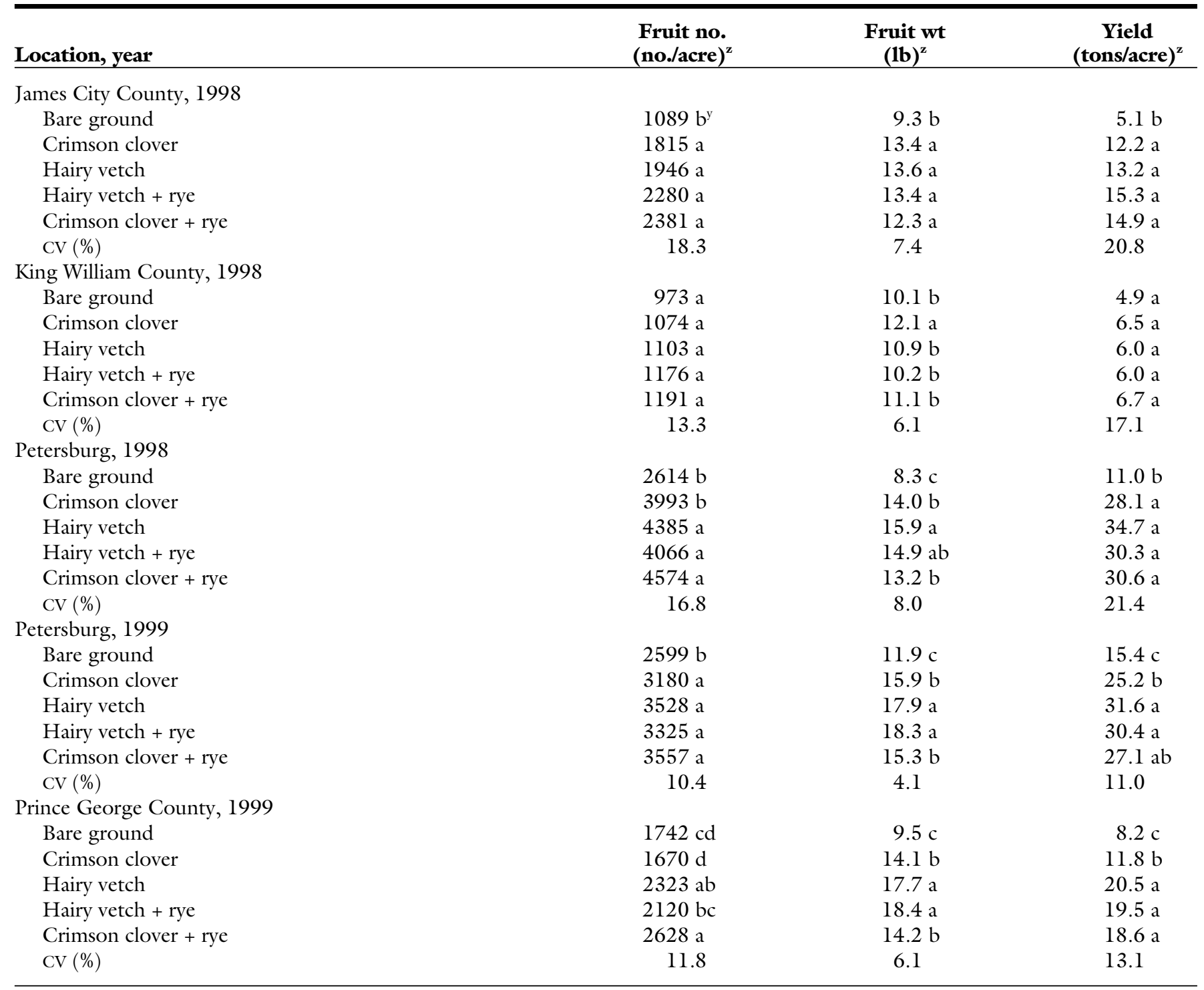

${ }^{\mathrm{z}} 1$ fruit/acre $=2.5$ fruit $/ \mathrm{ha} ; 1.0 \mathrm{lb}=0.45 \mathrm{~kg} ; 1.0 \mathrm{ton} / \mathrm{acre}=2.24 \mathrm{t} \cdot \mathrm{ha}^{-1}$.

y Means of cover crop treatments, within locations, were compared using Dunnett's procedure whereas the four cover crop treatments were compared to each other using Duncan's new multiple range test. Means followed by similar letters are not different at $P=0.05$.

An important point emerged from the experiments when performance of seedless watermelons was compared following legume cover crops with and without rye. Inclusion of rye with crimson clover increased seedless watermelon yields from 16.8 to 19.6 tons/ acre (37.7 to $\left.43.9 \mathrm{t} \cdot \mathrm{ha}^{-1}\right)$; whereas, inclusion of rye with hairy vetch did not increase the yield of seedless watermelons (Table 2), even though inclusion of rye with both crimson clover and hairy vetch increased the biomass yields. The dry biomass yield of crimson clover + rye was $1.1 \mathrm{oz} / \mathrm{ft}^{2}(347$ $\left.\mathrm{g} \cdot \mathrm{m}^{-2}\right)$; whereas, that from crimson clover alone was $0.9 \mathrm{oz} / \mathrm{ft}^{2}\left(284 \mathrm{~g} \cdot \mathrm{m}^{-2}\right)$. Similarly, the dry biomass yield of hairy vetch + rye was $1.2 \mathrm{oz} / \mathrm{ft}^{2}\left(378 \mathrm{~g} \cdot \mathrm{m}^{-2}\right)$; whereas, that from hairy vetch alone was $0.9 \mathrm{oz} / \mathrm{ft}^{2}\left(284 \mathrm{~g} \cdot \mathrm{m}^{-2}\right)$. Number of fruit and fruit yields were higher when cover crop treatment consisted of crimson clover + rye [2866 fruit/ acre and 19.6 tons/acre (7080 fruit/ ha and $\left.\left.43.9 \mathrm{t} \cdot \mathrm{ha}^{-1}\right)\right]$ as compared to crimson clover alone [ 2346 fruit/acre and 16.8 tons/acre (5796 fruit/ha and $37.7 \mathrm{t} \cdot \mathrm{ha}^{-1}$ )]. Number of fruit and fruit yields were not different when cover crop treatment consisted of hairy vetch + rye [2657 fruit/acre and 21.2 tons/acre (6405 fruit/ha and 45.6 $\left.\mathrm{t} \cdot \mathrm{ha}^{-1}\right)$ ] as compared to hairy vetch [2593 fruit/acre and 20.3 tons/acre (6563 fruit/ha and $\left.\left.47.6 \mathrm{t} \cdot \mathrm{ha}^{-1}\right)\right]$. There seems to be a synergistic advantage from including rye with crimson clover which did not exist with hairy vetch. This issue warrants further study.
In summary, legume cover crops, especially crimson clover + rye, hairy vetch + rye, and hairy vetch could be effectively used to meet $\mathrm{N}$ needs of seedless watermelons in a no-till production system. The results further showed that cover crops did not negatively affect the quality of seedless watermelons.

An informal market survey indicated that seedless watermelons can be sold wholesale for approximately $\$ 1.50$ to $\$ 2$ per fruit. The average fruit number of 2615 fruit/acre (6459 fruit/ha) from cover crop treatments, excluding the bare ground, translates to a gross income of $\$ 3,922 /$ acre $(\$ 9,687 /$ ha $)$ to $\$ 5,230 /$ acre $(\$ 12,918 / \mathrm{ha})$. At $\$ 1.50$ per fruit, the gross income from seedless watermelons produced fol- 
lowing the three highest yielding cover crop treatments [2866 fruit/acre (7079 fruit/ha) for rye + clover; 2657 fruit/acre (6563 fruit/ha) for hairy vetch; and 2593 fruit/acre (6405/ha) for hairy vetch + rye] would vary from $\$ 3,889$ /acre to $\$ 4,299 /$ acre $(\$ 9,606 /$ ha to $\$ 10,619 / \mathrm{ha})$. The yield levels in our experiments suggest that seedless watermelons can be a profitable summer cash crop for Virginia farmers. In this study. we did not record the yields of seeded watermelons produced on the male pollinator rows. However, the seeded fruit produced on these rows would also contribute towards the gross returns. The results also demonstrated that use of legume cover crops has the potential to decrease use of inorganic $\mathrm{N}$ fertilizers for commercial seedless watermelon production.

\section{Literature cited}

Abdul-Baki, A.A. and J.R. Teasdale. 1993. A no-tillage tomato production system using hairy vetch and subterranean clover mulches. HortScience 28:106-108.

Abdul-Baki, A.A., J.R. Teasdale, R.F. Korcak, D.J. Chitwood, and R.N. Huettel. 1996. Fresh-market tomato production in low-input alternative system using covercrop mulch. HortScience 31:65-69

Abdul-Baki, A.A., J.R. Teasdale, and R.F. Korcak. 1997. Nitrogen requirements of fresh-market tomatoes on hairy vetch and black polyethylene mulch. HortScience 32:217-221

Chisholm, D.N. and D.H. Picha. 1986. Effect of storage temperature on sugar and organic acid contents of watermelon. HortScience 21(4):1031-1033.

Csizinsky, A.A. and D.J. Schuster. 1982. Yield response of staked, fresh-market tomatoes to reduced use of fertilizers and insecticides. J. Amer. Soc. Hort. Sci. 107:648-652.
Doss, D.B., C.E. Evans, and W.A. Johnson. 1975. Rates of nitrogen and irrigation for tomatoes. J. Amer. Soc. Hort. Sci. 100:435-437.

Dubois, M.K., J.K. Giles, J.K. Hamilton, P.A. Rebers, and F. Smith. 1956. Colorimetric method for determination of sugars and related substances. Analytical chemistry. vol. 28. p. 350-356.

Hallberg, G.R. 1987. Agricultural chemicals in ground water: Extent and implications. Amer. J. Alt. Agr. 2:3-15.

Hills, F.J., F.E. Broadbent, and O.A. Lorenz. 1983. Fertilizer nitrogen utilization by corn, tomatoes, and sugarbeets. Agron. J. 75:423-426.

Meisinger, J.J., W.L. Hargrove, R.L. Mikkeelsen, J.R. Williams, and V.W. Benson. 1991. Effects of cover crops on groundwater quality, p. 57-68. In: W.L. Hargrove (ed.). Cover crops for clean water. Soil Water Conservation Soc. Amer., Ankeny, Iowa.

National Research Council. 1989. Alternative agriculture. Natl. Acad. Press, Wash., D.C.

Risse, L.A., J.K. Brecht, S.A. Sargent, S.J. Locascio, J.M. Crall, G.W. Elmstrom, and D.N. Maynard. 1990. Storage characteristics of small watermelon cultivars. J. Amer. Soc. Hort. Sci. 115(3):440-443.

SAS. 1996. SAS system for windows. SAS Institute, Inc., Cary, N.C.

Stivers, L.J. and C. Shennan. 1991. Meeting the nitrogen needs of processing tomatoes through winter cover cropping. J. Prod. Agr. 4:330-335.

U.S. Environmental Protection Agency. 1992. U.S. Environmental Protection Agency annual needs survey. USEPA, Office of Water, Wash., D.C.

Virginia Cooperative Extension. 1997. Commercial vegetable production recommendations. Va. Coop. Ext. Publ. p. 456420. 